\title{
Suicidal thinking, depression, and religiosity in a freedom-deprived population*
}

\author{
Cristina Ranuzi ${ }^{1,2}$ \\ (1) https://orcid.org/0000-0002-2470-1026 \\ Tamires Gomes dos Santos ${ }^{1,2}$ \\ (D) https://orcid.org/0000-0003-4583-3500 \\ Ana Cláudia Moura Caetano Araujo $0^{1,2}$ \\ (1) https://orcid.org/0000-0003-4924-9790 \\ Leiner Resende Rodrigues ${ }^{1}$ \\ (i) https://orcid.org/0000-0002-1176-8643
}

\begin{abstract}
Objective: to analyze the influence of sociodemographic variables, prison context, religiosity, and symptoms of depression on the presence of suicidal thinking in a population deprived of liberty. Method: a cross-sectional study with a quantitative approach, conducted with 228 participants, based on a sociodemographic questionnaire, on the prison context, and on the presence of suicidal thinking, from the Duke Religiosity Scale and the Depression, Anxiety and Stress Scale (DASS-21). Results: the variables that showed a statistically significant correlation were the following: female gender, not having a partner, working inside the penitentiary, being a primary defendant and using controlled medication, and females are 7.2 times more likely to present suicidal thinking, for each point more in the depression score, increases by $21 \%$ in the chances and not having a partner increases the chances of thinking about suicide by three times. Although the scores of religiosity were high, they did not present a statistically significant correlation with the presence of suicidal thinking. Conclusion: the prison context is complex and contains peculiarities that cause the involvement of mental health problems, as well as selfharming thoughts. Considering the relevance of the subject at issue, this work stands out in view of the scarce scientific production on the subject.
\end{abstract}

Descriptors: Suicidal Ideation; Prisoners; Depression; Religion; Mental Health; Health Care.

\section{How to cite this article}

Ranuzi C, Santos TG, Araujo ACMC, Rodrigues LR. Suicidal thinking, depression, and religiosity in a freedom-deprived population. Rev. Latino-Am. Enfermagem. 2020;28:e3368. [Access _ + - ]; Available in: DOI: http://dx.doi.org/10.1590/1518-8345.3713.3368. month day year 


\section{Introduction}

Freedom-Deprived People (FDP) constitute a risk group for suicide, presenting higher incidences when compared to the general population ${ }^{(1-2)}$. In the United States, for example, the occurrence of suicide among FDP is nine times higher when compared to the general population ${ }^{(1)}$. Incarceration is a traumatic experience, which implies social separation, family separation, limitation of routine activities, discrimination, poor access to the health services, permanence in a stressful environment, with precarious infrastructure and overcrowding, aspects that characterize the greater vulnerability of this population in relation to the presence of suicidal thoughts ${ }^{(3-5)}$.

Suicidal ideation is defined as the presence of thoughts in which the individual is the agent of his own death and the greater its magnitude and persistence, the greater the risk of eventual suicide ${ }^{(6-8)}$. Although the relationship between suicidal and mental disorders, especially depression and alcohol and drug abuse, are well established, factors such as conflict coping, violence, abuse or loss, isolation, and previous attempts also have a strong association with suicidal behavior ${ }^{(1)}$.

The approach to suicide is touchy, because it must be understood from the association of social, psychological, cultural, behavioral, and health factors, which act concomitantly and, because these are potentially preventable deaths, the focus should be on early identification of signs and appropriate management, and is an important target for prevention ${ }^{(9-12)}$. It is observed that the chances of making new attempts are ten times lower in people who received psychosocial intervention with regular care and due referral to a specialized health service $^{(13)}$.

Another factor that deserves to be highlighted, regarding prevention, is religiosity, since the evidence has revealed a positive and protective relationship with mental health(14-16). Participation in religious meetings attenuates the isolation experienced by the jailed population, provides psychic and spiritual well-being, creates bonds and there are indications that many of those dedicated to religious practices adopt a model of life transformation ${ }^{(16-17)}$.

However, few studies to date had investigated the prevalence of suicidal ideation and its correlates in a mixed sample of $\mathrm{FDP}^{(1)}$, being essential to foment new research in the area to identify risk factors as well as of protection, in order to provide instruments for professionals to support the person in the coping process $^{(9-10,18-19)}$.

In view of the above, this study aimed to analyze the influence of sociodemographic variables, prison context, religiosity and symptoms of depression on the presence of suicidal thinking in freedom-deprived population.

\section{Method}

A cross-sectional study, with a quantitative approach, held at the Professor Aluísio Ignácio de Oliveira state mixed penitentiary, located in the state of Minas Gerais, from May to July 2018.

The population consisted of 228 FDP, the following being considered as inclusion criteria: being male or female, convicted or provisional, and consent on participation. Participants who were unable to answer the instrument due to physical or psychological limiting factors were excluded from the study.

Sample recruitment involved non-probabilistic sampling of the study population and the sample calculation considered a prevalence of suicidal ideation of $23.7 \%$ during incarceration ${ }^{(12)}$, an accuracy of $5 \%$ and a $95 \%$ confidence interval for a finite population of 1,262 FDP. Using the Power Analysis and Sample Size application, in version 13 and introducing the values described above, a sample size of 228 individuals was obtained, and also considering a sampling loss of $20 \%$ the maximum number of interview attempts was 285 .

The collection questionnaire consisted of the following instruments: sociodemographic questionnaire, questionnaire of prison context and presence of suicidal thought, Duke University Religiosity Index (Durel), and the Depression, Anxiety and Stress Scale (DASS-21).

The data referring to the sociodemographic characteristics, the prison context, and the presence of self-reported suicidal thinking, were obtained from an instrument developed by the authors and submitted to appreciation and validation by three expert judges.

The instrument addresses the following study variables for the sociodemographic characteristics: date of birth, gender, marital status, schooling level, and family income, if the participant has a religion and, if so, which one.

The characteristics of the prison context were addressed based on questions related to study and work activities, such as: if the participant studies in the prison unit and, for those who do not study, they were asked if they would like to study; if they work in the unit and, for the negative answers, they were asked if they would like to work, while for those who work, they were asked what role they play. Questions regarding the date of admission to the penitentiary, the type of detention, the type of regime, whether they are a primary or repeat offender and whether they receive visits were also included. 
The following study variables were addressed, with regard to the presence of suicidal thinking: if the participant has thought about suicide at any time since imprisonment, what the frequency of that thought is, if they sought psychological assistance inside the unit, if they received psychological assistance and if they use some controlled medication.

The Durel scale was used to survey the religiosity score, a brief and easy to approach instrument, translated, and validated into Portuguese ${ }^{(20-22)}$. It has five items that capture three central dimensions of religiosity and that relate to health outcomes, namely: Organizational Religiosity (OR), Non-Organizational Religiosity (NOR), and Intrinsic Religiosity (IR) $)^{(20,22)}$.

OR comprises religious behaviors that occur in the context of the religious institution, such as attendance at formal religious activities. NOR, on the other hand, covers private religious behaviors, which occur without fixed locations, and can manifest themselves individually or in small family and informal groups. Finally, IR deals with a subjective dimension, which assesses how much religion can motivate or influence behaviors in the individual's life(20,22).

The first items on the scale assess OR and NOR and the last three items assess the IR. When analyzing the results, the scores of the three dimensions must be analyzed separately(21). For both OR and NOR, the score ranges from 1 to 6 points, while IR has a variation of 3 to 15 points. It is noteworthy that the higher the total scores, the greater the religiosity(22).

In order to proceed with the analysis, all items of the questions must be inverted to later perform the summation. For $\mathrm{OR}$ and NOR, the conversion results in: $1=6 ; 2=5 ; 3=4 ; 4=3 ; 3=2 ; 2=1$ and, for IR, the conversion results in: $1=5 ; 2=4 ; 3=3 ; 4=2 ; 5=1^{(20,22)}$.

For the classification of the scores, low OR scores $<3$ and high OR scores $\geq 4$ are considered. For NOR, $<3$ is low and $\geq 4$ is high. Regarding IR, it is considered high when the scores $\geq 10$ and low when the scores $<9^{(23)}$.

The survey for the depression symptoms was carried out using the DASS-21 scale, validated and adapted to Portuguese. It is a reduced, selfadministered instrument that contains 21 items that include three subscales which assess the symptoms of depression, anxiety, and stress ${ }^{(24-25)}$. The subscale of symptoms of depression is composed of items $3,5,10$, $13,16,17$ and 21 , the subscale of symptoms of anxiety is composed of items $2,4,7,9,15,19$ and 20, and the subscale of symptoms of stress is composed of items $1,6,8,11,12,14$ and 18 . Each item is scored from 0 to 3, with Likert-type answers, in which the individual evaluates how much each symptom was applied in the last week $^{(25)}$.
The four points on the scale are the following: $0=$ did not apply at all, $1=$ applied to some degree or for a short time; 2 = applied to a considerable degree, or for a good part of the time, and $3=$ applied a lot or most of the time. The final result is obtained by the sum of the scores of the items of each subscale, which subsequently must be multiplied by two and the classification is made according to the degree of severity ${ }^{(25)}$.

Initially, a pilot test was carried out with 10 participants, to verify the applicability of the instruments. The collection lasted approximately two months (May $22^{\text {nd }}$ to July $\left.19^{\text {th }}, 2018\right)$, respecting the deadline established by the Secretary of Prison Administration of the State of Minas Gerais (Secretaria de Administração Prisional do Estado de Minas Gerais, SEAP-MG). The interviews were conducted by the researchers, individually, with all the FDP that were handled within the prison unit, whether for routine medical care, for collecting laboratory tests, for welcoming care, for care by the Commission of Technical Classification (CTC), among others. The place for collection was a room in the health sector of the penitentiary and the duration of each interview was approximately 20 minutes.

It is noteworthy that the Free Consent Term was applied after clarification and any volunteer who presented some emotional discomfort, resulting from the application of the instruments, or presented some degree of depression, identified from the application of the scale, was welcomed by the interviewer and forwarded to psychological assistance in the prison unit, according to an agreement previously accomplished.

For statistical analysis, the Statistical Package for the Social Science (SPSS) software, version 21.0, was used. Regarding the characterization of the population according to sociodemographic variables, of the prison context and the presence or absence of suicidal thinking, categorical variables were submitted using distribution of absolute and relative frequencies and for the quantitative variables, measures of central trend and dispersion were used. In order to determine religiousness and symptoms of depression, the scale scores were summarized using centrality and dispersion measures.

As for the analysis of the relationship between sociodemographic, prison context, religiosity, and depression symptoms about the presence of suicidal thoughts, bivariate analyses were performed, such as the $t$ test for dichotomous predictors and Pearson's and Spearman's correlations for quantitative and ordinal predictors, respectively. The simultaneous contribution of sociodemographic, prison context, religiosity, and depression predictors of suicidal ideation included the analysis of multiple logistic regression. Associations with $p$-values $\leq 0.05$ were considered statistically 
significant and an alpha significance level of $5 \%$ was considered.

This study was submitted to the appreciation and approval of the SEAP-MG and to the Ethics Committee in Research with Human Beings of the Federal University of Triângulo Mineiro, under approval number 2,649,472.

\section{Results}

The study population consisted of 228 freedomdeprived individuals, 189 (82.9\%) of whom were male and $39(17.1 \%)$, female. They were between 18 and 74 years old, with a mean of 33.48 years old, the median being 32 years old and the standard deviation being 10.2 years old. Regarding marital status, 106 (46.5\%) were single.

It was verified that $98(43 \%)$ individuals had not completed elementary school and that the most prevalent family income was one minimum wage, $65(28.5 \%)$, followed by those who reported an income of up to three minimum wages, 58 (25.4\%). The largest proportion, $210(92.1 \%)$ reported having a religion, and of these, 104 (49.5\%) were Catholics, 73 (34.8\%) Evangelicals, 29 (13.8\%) Spiritists, 2 (1\%) Jehovah's Witness, and 2 (1\%) professed other religions.
As for the characteristics of the prison context, it was verified that $168(73.7 \%)$ participants were convicted and that $60(26.3 \%)$ were still awaiting trial, with $181(79.4 \%)$ remaining in a closed regime and $47(20,6 \%)$ in a semi-open regime. Most of the individuals, $141(61.8 \%)$, reported being repeat offenders in prison. Their seclusion time varied between 0 and 5,016 days (approximately 13 years and 9 months), with a mean of 585.11 days (approximately 1 year and 6 months), a median of 329 days, and a standard deviation of 787.39 days (approximately 2 years and 1 month).

Only $15(6.6 \%)$ participants study within the prison unit and, among those who do not study, $181(85 \%)$ say they would like to study. As for the presence of an employment relationship, only $42(18.4 \%)$ participants had some activity; however, among the participants who did not have any activity, the majority, 172 (92.5\%), demonstrated the desire to work. Among the activities offered, handicrafts were the most prevalent, $20(47.6 \%)$. With regard to visits, $109(47.8 \%)$ participants declared receiving them and it was identified that female participants $(38.5 \%)$ receive fewer visits when compared to male $(49.7 \%)$.

Table 1 displays the centrality and dispersion measures from the answers to the religiosity scale.

Table 1 - Central tendency and dispersion measures for the dimensions of the religiosity scale applied to freedom-deprived individuals in a state mixed penitentiary. Uberaba, MG, Brazil, 2018

\begin{tabular}{cccccc}
\hline Dimension & Mean & Median & Standard Deviation & Minimum Value & Maximum value \\
\hline $\mathrm{OR}^{*}$ & 4.61 & 5.00 & 1.599 & 6 & 1 \\
$\mathrm{NOR}^{\dagger}$ & 5.04 & 5.00 & 0.984 & 2.662 & 4 \\
$\mathrm{IR}^{\ddagger}$ & 12.07 & 13.00 & 15 & 4 \\
\hline
\end{tabular}

${ }^{*} \mathrm{OR}=$ Organizational religiosity $;{ }^{+} \mathrm{NOR}=$ Non-organizational religiosity; ${ }^{\ddagger} \mathrm{IR}=$ Intrinsic religiosity

According to the classification score, $184(80.7 \%)$ participants had high organizational religiosity, $217(95.2 \%)$ high non-organizational religiosity, and 187 (82\%) high intrinsic religiosity.

Regarding the evaluation of the subscale of symptoms of depression, a variation from zero to 42 points was observed, with a mean of 8.50 points, median of 6.0 points, and standard deviation of 8.93 points. Table 2 contains the result of the evaluation for the subscale of depression symptoms as per severity grade.

Table 3 shows the variables related to the characterization of suicidal thinking.

From the bivariate analysis, it is noted that the statistically significant variables were the following: being female, having no partner, working within the penitentiary, being a primary defendant, and using controlled medication, as shown in Table 4.

From the binomial multiple logistic regression, it was possible to confirm the correlations previously mentioned, as shown in Table 5. It is observed that the female gender has a 7.2 times greater chance of displaying suicidal thoughts than the male gender. As for the total depression score, it appears that for each additional point in the depression score, the chances of having suicidal thoughts increase by $21 \%$. For the marital status variable, which in the logistic regression was dichotomized as having or not having a partner, it appears that the individuals who do not have a partner are three times more likely to think about suicide when compared to those who have a partner. 
Table 2 - Result of the evaluation for the subscale of depression symptoms applied to freedom-deprived individuals in a state mixed penitentiary. Uberaba, MG, Brazil, 2018

\begin{tabular}{|c|c|c|}
\hline Category & N & $\%$ \\
\hline Normal & 141 & 61.8 \\
\hline Mild & 28 & 12.3 \\
\hline Moderate & 38 & 16.7 \\
\hline Severe & 10 & 4.4 \\
\hline Extremely severe & 11 & 4.8 \\
\hline
\end{tabular}

Table 3 - Distribution of the frequency of the variables related to suicidal thinking in freedom-deprived individuals in a state mixed penitentiary. Uberaba, MG, Brazil, 2018

\begin{tabular}{|c|c|c|c|}
\hline Variables & Categories & $\mathbf{n}$ & $\%$ \\
\hline \multirow[t]{2}{*}{ Presence of suicidal thoughts since incarceration } & Yes & 48 & 21.1 \\
\hline & No & 180 & 78.9 \\
\hline \multirow[t]{5}{*}{ Frequency of suicidal thinking since incarceration } & One & 17 & 35.4 \\
\hline & Two & 8 & 16.7 \\
\hline & Three & 5 & 10.4 \\
\hline & Four & 3 & 6.3 \\
\hline & Five or more & 15 & 31.3 \\
\hline \multirow{2}{*}{$\begin{array}{l}\text { In the presence of suicidal thought, they sought psychological assistance } \\
\text { in the prison unit }\end{array}$} & Yes & 24 & 50 \\
\hline & No & 24 & 50 \\
\hline \multirow[t]{2}{*}{ If they sought, they received psychological care } & Yes & 15 & 62.5 \\
\hline & No & 9 & 37.5 \\
\hline \multirow[t]{2}{*}{ Refers using controlled medication } & Yes & 80 & 35.1 \\
\hline & No & 148 & 64.9 \\
\hline
\end{tabular}

Table 4 - Association between sociodemographic and prison context factors and the presence of suicidal thinking in freedom-deprived individuals in a state mixed penitentiary. Uberaba, MG, Brazil, 2018

\begin{tabular}{|c|c|c|c|c|c|}
\hline \multirow{2}{*}{ Variables } & \multicolumn{2}{|c|}{ Presence of suicidal thought } & \multirow[b]{2}{*}{$\mathrm{PR}^{*}$} & \multirow[b]{2}{*}{$\mathrm{POR}^{\dagger}$} & \multirow[b]{2}{*}{$p^{\ddagger}$} \\
\hline & Yes & No & & & \\
\hline \multicolumn{6}{|l|}{ Gender } \\
\hline Female & $\begin{array}{c}20 \\
(51.3 \%)\end{array}$ & $\begin{array}{c}19 \\
(48.7 \%)\end{array}$ & $\begin{array}{c}3.462 \\
2.188-5.476)\end{array}$ & $\begin{array}{c}6.053 \\
(2.873-12.752)\end{array}$ & $<0.001$ \\
\hline Male & $\begin{array}{c}28 \\
(14.8 \%)\end{array}$ & $\begin{array}{c}161 \\
(85.2 \%)\end{array}$ & & & \\
\hline \multicolumn{6}{|c|}{ Presence of a partner } \\
\hline No & $\begin{array}{c}34 \\
(28.3 \%)\end{array}$ & $\begin{array}{c}86 \\
(71.7 \%)\end{array}$ & $\begin{array}{c}2.186 \\
(1.242-3.848)\end{array}$ & $\begin{array}{c}2.654 \\
(1.335-5.280)\end{array}$ & 0.004 \\
\hline Yes & $\begin{array}{c}14 \\
(13 \%)\end{array}$ & $\begin{array}{c}94 \\
(87 \%)\end{array}$ & & & \\
\hline \multicolumn{6}{|c|}{ Working inside the penitentiary } \\
\hline Yes & $\begin{array}{c}16 \\
(38.1 \%)\end{array}$ & $\begin{array}{c}26 \\
(61.9 \%)\end{array}$ & $\begin{array}{c}2.214 \\
(1.346-3.644)\end{array}$ & $\begin{array}{c}2.962 \\
(1.427-6.145)\end{array}$ & 0.003 \\
\hline No & $\begin{array}{c}32 \\
(17.2 \%)\end{array}$ & $\begin{array}{c}154 \\
(82.8 \%)\end{array}$ & & & \\
\hline \multicolumn{6}{|l|}{ Type of defendant } \\
\hline Primary & $\begin{array}{c}26 \\
(29.9 \%)\end{array}$ & $\begin{array}{c}61 \\
(70.1 \%)\end{array}$ & $\begin{array}{c}1.915 \\
(1.161-3.161)\end{array}$ & $\begin{array}{c}2.306 \\
(1.208-4.400)\end{array}$ & 0.010 \\
\hline Repeat offender & $\begin{array}{c}22 \\
(15.6 \%)\end{array}$ & $\begin{array}{c}119 \\
(84.4 \%)\end{array}$ & & & \\
\hline \multicolumn{6}{|c|}{ Use of controlled medication } \\
\hline Yes & $\begin{array}{c}26 \\
(32.5 \%)\end{array}$ & $\begin{array}{c}54 \\
(67.5 \%)\end{array}$ & $\begin{array}{c}2.186 \\
(1.328-3.599)\end{array}$ & $\begin{array}{c}2.758 \\
(1.438-5.288)\end{array}$ & 0.002 \\
\hline No & $\begin{array}{c}22 \\
(14.9 \%)\end{array}$ & $\begin{array}{c}126 \\
(85.1 \%)\end{array}$ & & & \\
\hline
\end{tabular}

$\overline{{ }^{*} \mathrm{PR}}=$ Prevalence ratio; ${ }^{\mathrm{P} O \mathrm{R}}=$ Prevalence odds ratio; ${ }^{{ }^{*} \text { Chi Square }}$ Test 
Table 5 - Analysis of binomial multiple logistic regression having as an outcome the presence or absence of suicidal thought in freedom-deprived individuals in a state mixed penitentiary. Uberaba, MG, Brazil, 2018

\begin{tabular}{lccr}
\hline \multicolumn{1}{c}{ Variables } & p-value & Adjusted POR $^{*}$ & Confidence Interval $^{\ddagger}$ \\
\hline Gender & 0.001 & 7.197 & $2.358-21.968$ \\
Depression (total score) & $<0.001$ & 1.216 & $1.142-1.296$ \\
IR & 0.477 & 0.941 & $0.796-1.112$ \\
Marital status & 0.010 & 3.446 & $1.348-8.804$ \\
Type of regime & 0.069 & 3.296 & $0.911-11.925$ \\
\hline
\end{tabular}

${ }^{*} \mathrm{p}<0.005 ;{ }^{+} \mathrm{POR}=$ Prevalence odds ratio; ${ }^{\ddagger} 95 \% \mathrm{CI}$

\section{Discussion}

From this study, it was found that $21.1 \%$ of the participants reported suicidal ideation since the beginning of incarceration. In the scientific literature, no study was found with a methodology similar to this, with regard to the approach of suicidal ideation among FDP, thus making it difficult to compare the data obtained with those from other authors.

The study with the methodological design closest to this was carried out in Israel, but only with 46 incarcerated women, and found a considerably higher prevalence, since more than $50 \%$ of the participants reported a history of suicidal ideation and attempted self-extermination during incarceration ${ }^{(26)}$.

Other international research studies, with different methodologies, found varied values. In Belgium, the Paykel Suicide Scale (PSS) found a prevalence of suicidal ideation of $43.1 \%$ over life, and of $23.7 \%$ during incarceration $^{(12)}$. In the United States, by means of the suicide scale of the Morey Personality Inventory, it was evidenced that $16 \%$ of the participants had a clinically significant suicidal ideation in incarceration, while in Costa Rica a $10.2 \%$ prevalence was found by using the BSI scale ${ }^{(1-2)}$.

In Ethiopia, almost $17 \%$ of the total inmates expressed the idea of committing suicide, $16.6 \%$ have already planned it, and $11.9 \%$ have made at least one attempt since detention(27). In Colombia, the percentages of high suicidal ideation were higher than those found in the general population. Among 154 prisoners in a prison, $14.9 \%$ had high suicidal ideation, $20.1 \%$ medium, and $64.9 \%$ low $^{(27)}$.

Based on these data, it can be seen that there are still few studies on this topic, mainly those covering the FDP in Brazil(3). Even so, it is possible to infer that the prevalence of suicidal thinking among the FDP is higher when compared to the general population(12,27-29).

Thus, it is inferred that incarceration increases the individual's predisposition to the involvement in suicidal ideation, due to factors such as the weakening of the social support system, overcrowding, precarious infrastructure, which require personal adaptive processes in the face of change of reality and favor the onset of symptoms such as anxiety, stress, depression, and self-injurious thoughts ${ }^{(3,27-28,30-33)}$.

As for the frequency of suicidal thinking, the majority $(64.6 \%)$ of the individuals reported having thought about it more than once. As for the psychological care provided by the prison unit, half of the participants who claimed to have thought of suicide requested care at the unit and, of these, $62.5 \%$ said they had received it. For this specific information, no data were found in the literature to enable discussion. However, there is evidence that the mental health services in prison units are limited(33).

From the bivariate analysis, it was verified that being female $(p<0.001)$, not having a partner $(p=0.004)$, working within the penitentiary $(p=0.003)$, being a primary defendant $(p=0.010)$, having self-reported depression $(p<0.001)$ and making use of controlled medication $(p=0.002)$ were the statistically significant variables.

From the binomial multiple logistic regression, the aforementioned correlations were confirmed, since the statistically significant variables were gender $(p=0.001)$, total depression score $(p<0.001)$, and marital status $(p=0.010)$, being that female gender increases by 7.2 times the chance of having suicidal thoughts ( $P O R=7.197)$, not having a partner increases it by 3 times $(P O R=3.466)$ and, for each additional point on the total score of the depression scale, they increase by $21 \%$ the chance of presenting suicidal thoughts ( $P O R=1.216)$.

Reinforcing these findings, research conducted in China and the United States, the first two countries with the largest prison population in the world, indicated that psychiatric morbidities, sociodemographic variables, fragile social support, personality traits, and history of attempted suicide are significantly related to suicidal ideation in prison populations ${ }^{(1,30,34)}$.

It is noteworthy that individuals under 30 years old $(p=0.04)$, who do not have a partner $(p=0.04)$, with a history of intrafamily violence $(p=0.03)$, previous suicide attempt $(p=0.001)$, who are diagnosed with a psychiatric disorder throughout their lives $(p=0.02)$, 
and incarcerated for less than one year $(p=0.001)$ showed more probability for developing suicidal ideation(3,12,27,29-31,35). Adding to this aspect, the lack of social support and being exposed to the suicidal behavior of fellow inmates increased by two times the chances of experiencing suicidal ideation ${ }^{(12,30)}$.

In contrast, in Europe, the decrease in the chances of suicidal ideation was significantly associated with individuals with history of previous incarceration $(p=0.001)$, who did some work during incarceration $(p=0.039)$, who maintained contact with family and friends $(p=0.030)$, and with perceived safety $(p=0.002)^{(12)}$.

These data are in line with a study carried out in Chile, which was based on the investigation of 132 consummated suicide occurrences in FDP, of which $66.7 \%$ had previous admissions to the prison system, $73.5 \%$ were single, $84.8 \%$ were not engaged in any work activity, and $43.2 \%$ were facing some degree of depression ${ }^{(3)}$.

As for the fact that women are more likely to have suicidal thoughts than men, the results corroborate those from other authors, who identified the same relationship both for FDP and among the general population(26,35-36). Deaths by suicide are approximately three times higher among men than among women. Conversely, suicide attempts are, on average, three times more frequent among women ${ }^{(19)}$. The trend of men being associated with risky behaviors, higher levels of strength, easier access to more lethal means, and the fact that women are more concerned with health and seek help with less resistance, may explain this circumstance ${ }^{(13,19)}$.

Regarding marital status, it was verified that living alone increases the risk of suicide, with higher rates among divorced people or individuals who never married(19). The results of this research ratify those found in the literature, since there was a significant correlation between not having a partner and the presence of suicidal ideation $(p=0.004)$. It is added that another study found the same correlation $(p=0.004)$ and, like other authors, states that having a partner is a

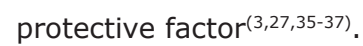

Although work during incarceration has been associated in other research studies with less suicidal ideation, this study identified an inverse correlation, since labor activity was correlated with an increase in suicidal ideation $(p=0.003)^{(2-3,12,27)}$. Participation in work activities guarantees FDP the benefit of the remission of the penalty in the proportion of one day redeemed for every three days worked; however, its inclusion is subject to the multi-professional evaluation of the technical classification committee, which analyzes physical, psychological, behavioral, and safety conditions of the concerned individuals. It is necessary to take into account possible stress factors inherent to these activities, such as a rigorous daily review when leaving and returning from work, the reduced number of vacancies, and the consequent lack of variety of these occupations, which directs them to perform work that is not necessarily the preference or aptitude of the FDP. In addition, there is a severe demand for compliance with disciplinary rules, as any infringement of a medium or severe nature results in the suspension of this benefit ${ }^{(38)}$. It is emphasized that this condition should be better explored, in order to understand the representation of work for this population, as no article with a pertinent explanation was found.

Another variable that correlated with the existence of suicidal ideation was the fact that the FDI was a primary defendant, $(p=0.010)$, a data consistent with the fact that a history of previous incarceration was considered a protective factor $(p=0.001)^{(12)}$.

Regarding to the fact that depression has considerably increased the chances of the FDP to think about suicide, there is a consensus among specialized health groups that the mental illness usually associated with suicide is depression ${ }^{(39)}$. It is estimated that it was present in at least $50 \%$ of the consummated suicides $^{(19,39-40)}$. For both the general population and the FDP, depression is an important risk factor for suicidal ideation, with a positive correlation ${ }^{(10,26,31,41-45)}$.

Regarding controlled drugs, $35.1 \%$ of the participants reported using them and a statistically significant correlation was identified with the presence of suicidal ideation; however, for this information, no studies were found that favored any comparison.

With regard to religiosity, even though the evidence indicates that it acts as a protective factor for the presence of suicidal ideation, in this study it was not possible to make such confirmation, since there was no statistically significant correlation $(p=0.477 / P O R=0.941)$, in accordance with other authors ${ }^{(12-46)}$. There is still no evidence that religiosity significantly reduces suicide in prison, and it is suggested that perhaps this is due to the absence of studies that specifically address the impact

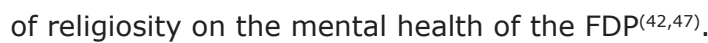

Among the limitations of this study, it is worth highlighting the convenience sampling to the detriment of the probabilistic sampling, since the prison unit did not have the necessary number of prison officers to exclusively remove the FDP that were randomly selected. Moreover, cross-sectional studies have a unique measurement, while the follow-up of the longitudinal studies guarantees a wider data range. The fact is also added that at least one prison guard followed each participant at all times, which may 
have led to the underreporting of some information, incorporating possible biases.

Despite these limitations, as an important strength of this study the fact stands out that it is perhaps one of the first surveys carried out in Brazil to investigate suicidal ideation, depression, and religiosity, as well as the sociodemographic characteristics and the prison context among incarcerated men and women. Thus, the substantiality in continuing studies like this stands out, especially since it is a stigmatized and constantly growing population.

The context in which FDP are inserted is complex and has peculiarities that allow for the onset of mental health problems. Thus, better portraying the reality of this population and its profile, understanding the violence of death as a result of suicide, as well as understanding the correlated factors, can contribute to the instrumentalization of future intervention actions and to the promotion of barriers to their occurrence.

\section{Conclusion}

This study identified that $21.1 \%$ of the participants declared suicidal ideation after incarceration and, as for the variables analyzed, being female, not having a partner, working within the penitentiary, being a primary defendant, and using controlled medications were those that had some influence on the presence of this thought. It was also verified that being female increases by 7.2 times the chance of having suicidal thoughts, that not having a partner increases it by 3 times and that, for each additional point on the total score of the depression scale, the increase is $21 \%$ in the chances of presenting the same thought. It is concluded that the proposed objectives were achieved and that the study contributes to measures that can help in the identification of people at risk, such as the elaboration of new intervention proposals, the prevention of suicidal behavior, and health promotion.

\section{References}

1. Schaefer KE, Esposito-Smythers C, Tangney JP. Suicidal ideation in a United States jail: Demographic and psychiatric correlates. J Forens Psychiatry Psychol. 2016;27(5):698-704. doi: 10.1080/14789949.2016.1193886.

2. Chacon MB, Cueva MM. Suicidal ideation in prisoners: A proposal for your attention. InterSedes. [Internet]. 2014 [cited Jan 10, 2019];15(32):223-48. Available from: https://www.scielo.sa.cr/scielo.php?script=sci_ar ttext\&pid=S2215-24582014000300223

3. Ceballos-Espinoza F, Chávez-Hernández AM, PadillaGallegos GM, Leenaars AA. Suicide in Chilean prisons during the 2006-2015 decade. Rev Crim. [Internet]. 2016 [cited Jan 10, 2019];58(3):101-18. Available from: http://www.scielo.org.co/scielo.php?script=sci_ abstract\&pid=S1794-31082016000300009

4. Andreoli SB, Santos MM, Quintana MI, Ribeiro WS, Blay SL, Taborda JGV, et al. Prevalence of Mental Disorders among Prisoners in the State of Sao Paulo, Brazil. PLoS One. 2014;9(2). doi: 10.1371/journal. pone.0088836

5. Navarro RB, Paredes-Carbonell JJ, Juan-Ulpiano DA, González Rubio J, Monzó CP, Martínez LM, et al. Participatory design guide for mental health Promotion in prisons. Rev Esp Sanid Penit. 2013;15(2):44-53. doi: 10.4321/S1575-06202013000200002.

6. American Psychiatric Association. Practice guideline for the assessment and treatment of patients with suicidal behaviors. Filadélfia: APA; 2010 [cited Jan 10, 2019]. Available from: http://www.appi.org/CustomerService/ Pages/Permissions.aspx

7. Pinto RDPM. Ideação Suicida e Sintomatologia Psicopatológica em Indivíduos Toxicodependentes. [dissertação]. Porto: Universidade Portucalense Infante D. Henrique; 2011. [Acesso 10 jan 2019]. Disponível em: http://repositorio.uportu.pt/jspui/handle/11328/52 8. Bertolote JM, Mello-Santos C, Botega N. Detecting suicide risk in psychiatric emergency services. Rev Bras Psiquiatr. 2010;32(2):587-95. doi: 10.1590/S151644462010000600005

9. Moreira LCO, Bastos PRHO. Prevalence and risk factors associated with suicidal ideation in adolescents: literature review. Psicol Esc Educ. 2015;19(3):445-53. doi: 10.1590/2175-3539/2015/0193857

10. Vasconcelos EF. Avaliação psicológica e os fatores de risco do suicídio. Rev Especialize. [Internet]. 2016 [Acesso 10 jan 2019];1(12);1-13. Disponível em: https://www.ipog.edu.br/revista-especialize-online/ edicao-n12-2016/avaliacao-psicologica-e-os-fatoresde-risco-do-suicidio/

11. World Health Organization. Constitution of the World Health Organization. Preventing Suicide: A global imperative. [Internet]. Geneva: WHO; 2014 [cited Jan 10, 2019]. Available from: https://www.who.int/ mental_health/suicide-prevention/exe_summary_ english.pdf

12. Favril L, Laenen FV, Vandeviver C, Audenaert K. Suicidal ideation while incarcerated: Prevalence and correlates in a large sample of male prisoners in Flanders, Belgium. Int J Law Psychiatry. 2017;55:19-28. doi: $10.1016 /$ j.ijlp.2017.10.005

13. Calixto FM, Zerbini T. Epidemiology of suicide in Brazil between the years 2000 and 2010. Saúde Ética \& Justiça. 2016;21(2):45-51. doi: 10.11606/issn.23172770.v21i2p45-51 
14. Moreira-Almeida A, Lotufo Neto F, Koenig HG. Religiousness and mental health: a review. Braz J Psychiatry. 2006;28(3):242-50. doi: 10.1590/S151644462006005000006

15. Paiva MCA. O papel da religiosidade e do suporte social na depressão: resultados do Estudo Epidemiológico São Paulo Megacity Mental Health Survey. [dissertação]. Vitória: Universidade Federal do Espírito Santo; 2014 [Acesso 10 jan 2019]. Disponível em: http://bdtd.ibict. br/vufind/Record/UFES_3d72a2208fca63a57485c12d62 $55 \mathrm{dc} 71$

16. Ribeiro FML, Minayo MCS. The role of religion in the promotion of health, in the prevention of violence and in the rehabilitation of individuals involved in criminal activity: literature review. Ciênc Saúde Coletiva. 2014;19(06): 1773-89. doi: 10.1590/1413-81232014196.13112013

17. Livramento AM, Rosa EM. Homens no cárcere: estratégias de vida na prisão. Pesqui Prát Psicossociais. [Internet]. 2016 [Acesso 10 jan 2019];11(2): 412-26. Disponível em: http://pepsic.bvsalud. org/scielo.php ?script=sci_abstract $\&$ pid $=$ S1809$89082016000200011 \& \operatorname{lng}=p t \& n r m=i s o \& t \mid n g=p t$ 18. Ministério da Saúde (BR). Secretaria de Vigilância em Saúde. Boletim Epidemiológico: Perfil epidemiológico das tentativas e óbitos por suicídio no Brasil e a rede de atenção à Saúde. [Internet]. Brasília: MS; 2017 [Acesso 10 jan 2019]. Disponível em: http://portalarquivos2.saude. gov.br/images/pdf/2017/setembro/21/2017-025-Perfilepidemiologico-das-tentativas-e-obitos-por-suicidio-noBrasil-e-a-rede-de-atencao-a-saude.pdf

19. Associação Brasileira de Psiquiatria (ABP). Suicídio: informando para prevenir. [Internet]. Brasília: Conselho Federal de Medicina; 2014 [Acesso 10 jan 2019]. Disponível em: https://www.cvv.org.br/wp-content/ uploads/2017/05/suicidio_informado_para_prevenir_ abp_2014.pdf

20. Koenig H, Parkerson GR, Meador KG. Religion index for psychiatric research. Am J Psychiatry. [Internet]. 1997 [cited Jan 10, 2019];154(6):885-6. Available from: https://www.ncbi.nlm.nih.gov/pubmed/9167530 21. Moreira-Almeida A, Peres MF, Aloe F, Lotufo Neto F, Koenig HG. Portuguese version of Duke Religious Index - DUREL. Arch Clin Psychiatry (São Paulo). 2008;35(1): 31-2. doi: 10.1590/S0101-60832008000100006

22. Lucchetti G, Granero Lucchetti AL, Peres MF, Leão FC, Moreira-Almeida A, Koenig HG. Validation of the Duke Religion Index: DUREL (Portuguese Version). J Relig Health. 2012;51(2):579-86. doi: 10.1007/s10943010-9429-5

23. AbdelGawad N, Chotalia J, Parsaik A, Pigott T, Allen M. Religiosity in acute psychiatric inpatients: relationship with demographics, clinical features, and length of stay.
J Nerv Ment Dis. 2017;205(6):448-52. doi: 10.1097/ nmd.0000000000000688

24. Lovibond PF, Lovibond SH. The structure of negative emotional states: comparison of the Depression Anxiety Stress Scales (DASS) with the Beck Depression and Anxiety Inventories. Behav Res Ther. [Internet]. 1995 [cited Jan 10, 2019];33(3):335-43. Available from: https://www.ncbi.nlm.nih.gov/pubmed/7726811

25. Vignola RCB, Tucci AM. Adaptation and validation of the Depression, Anxiety and Stress Scale (DASS) to Brazilian Portuguese. J Affect Dis. 2014;155:104-9. doi: $10.1016 /$ j.jad.2013.10.031

26. Chen G, Gueta K. Lifetime History of Suicidal Ideation and Attempts Among Incarcerated Women in Israel. Psychol Trauma. 2017;9(5):596-604. doi: $10.1037 /$ tra0000277

27. Beyen TK, Dadi AF, Dachew BA, Muluneh NY, Bisetegn TA. More than eight in every nineteen inmates were living with depression at prisons of Northwest Amhara Regional State, Ethiopia, a cross sectional study design. BMC Psychiatry. 2017;17:31. doi: 10.1186/ s12888-016-1179-9

28. Santos BF, Silva SGV, Formiga NS, Estevam ID. Depression behind bars: a possible convict symptom. Psicol inFormação. 2016;19(19):63-82. doi: 10.15603/2176-0969/pi.v19n19p63-82

29. Gates ML, Turney A, Ferguson E, Walker V, StaplesHome M. Associations among Substance Use, Mental Health Disorders, and Self-Harm in a Prison Population: Examining Group Risk for Suicide Attempt. Int J Environ Res Public Health. 2017;14(3):1-16. doi: 10.3390/ ijerph14030317

30. Moreira NAC, Gonçalves RA. Perturbação mental e ideação suicida entre reclusos preventivos. Anal Psicol. [Internet]. 2010 [Acesso 10 jan 2019];28(1): 133-48. Disponível em: http://www.scielo.mec. pt/scielo.php?script =sci_abstract\&pid=S0870$82312010000100010 \&$ lng =pt\&nrm=iso\&tlng=pt

31. Bardale RV, Dixit PG. Suicide behind bars: A 10-year retrospective study. Indian J Psychiatry. 2015;57(1): 81-4. doi: 10.4103/0019-5545.148531

32. Mandracchia J, Smith PN. The Interpersonal Theory of Suicide Applied to Male Prisoners. Suicide Life Threat Behav. 2015;45(3):293-301. doi: 10.1111/sltb.12132

33. DeGroote J. Weighing the Eighth Amendment: Finding the Balance Between Treating and Mistreating Suicidal Prisoners. J Const Law. [Internet]. 2014 [cited Jan 10, 2019];17(1):259. Available from: https:// scholarship.law.upenn.edu/jcl/vol17/iss1/4/

34. Zhang J, Grabiner VE, Zhou Y, Li N. Suicidal ideation and its correlates in prisoners: a comparative study in China. Crisis. 2010;31(6):335-42. doi: 10.1027/02275910/a000055 
35. Nock MK, Borges G, Bromet EJ, Alonso J, Angermeyer $M$, Beautrais $A$, et al. Cross-national prevalence and risk factors for suicidal ideation, plans and attempts. $\mathrm{Br}$ J Psychiatry. 2008;192(2):98-105. doi: 10.1192/bjp. bp.107.040113

36. Botega NJ, Marín-León L, Oliveira HB de, Barros MB de A, Silva VF, Dalgalarrondo P. Prevalence of suicidal ideation, suicide plans, and attempted suicide: a population-based survey in Campinas, São Paulo State, Brazil. Cad Saúde Pública. 2009;25(12):2632-8. doi: $10.1590 / S 0102-311 \times 2009001200010$

37. Cunha FA, Baptista M, Carvalho LF. Documentary analysis of the suicides in the Jundiaí region between 2004 and 2014. Salud Soc. 2016;7:212-22. doi: 10.22199/S07187475.2016.0002.00006

38. Ministério da Justiça e Segurança Pública (BR). Portaria 3 da Vara de Execuções Penais de 4 de Abril de 2018. Dispõe sobre o Trabalho do(a) preso(a) no âmbito do sistema penitenciário do Distrito Federal e estabelece critérios de classificação para atividades laborais internas e externas. Diário da Justiça Eletrônico. Brasília, 13 abr 2018 [Acesso 10 jan 2019]. Disponível em: https://www.tjdft.jus.br/publicacoes/publicacoesoficiais/portarias-serventias-judiciais/2018/portariavep-03-de-04-04-2018

39. American Association of Suicidology. Depression and Suicide Risk. [Internet]. Washington: AAS; 2014 [cited Jan 10, 2019]. Available from: https://www.suicidology. org/portals/14/docs/resources/factsheets/2011/ depressionsuicide2014.pdf.

40. World Health Organization. Depression and Other Common Mental Disorders: Global Health Estimates. [Internet]. Geneva: WHO; 2017 [cited Jan 10, 2019]. Available from: https://www.who.int/mental_health/ management/depression/prevalence_global_health_ estimates/en/

41. Ayhan G, Arnal R, Basurko C, About V, Pastre A, Pinganaud $E$, et al. Suicide risk among prisoners in French Guiana: prevalence and predictive factors. BMC Psychiatry. 2017;17:156. doi: 10.1186/s12888-0171320-4

42. Eytan A. Religion and mental health during incarceration: a systematic literature review. Psychiatr
Q. 2011;82(4):287-95. doi: 10.1007/s11126-0119170-6

43. Bebbington $P$, Jakobowitz $S$, McKenzie N, Killaspy $H$, Iveson R, Duffield G, et al. Assessing needs for psychiatric treatment in prisoners: 1 . Prevalence of disorder. Soc Psychiatry Psychiatr Epidemiol. 2017;52(2): 221-9. doi: 10.1007/s00127-016-1311-7

44. Constantino P, Assis SG, Pinto LW. The impact of prisons on the mental health of prisoners in the state of Rio de Janeiro, Brazil. Ciênc Saúde Coletiva. 2016;21(7):2089-100. doi: 10.1590/141381232015217.01222016

45. Shrestha G, Yadav DK, Sapkota N, Baral D, Yadav BK, Chakravartty A, et al. Depression among inmates in a regional prison of eastern Nepal: a cross-sectional study. BMC Psychiatry. 2017;17(1):348. doi: 10.1186/ s12888-017-1514-9

46. Julião EF. Reincidência criminal e penitenciária: aspectos conceituais, metodológicos, políticos e ideológicos. Rev Bras Sociologia. [Internet]. 2016 [cited Jan 10, 2019];4(7):265-92. Available from: https:// dialnet.unirioja.es/descarga/articulo/5896088.pdf 47. Minayo MCS, Ribeiro AP. Health conditions of prisoners in the state of Rio de Janeiro, Brazil. Ciênc Saúde Coletiva. 2016;21(7):2031-40. doi: $10.1590 / 1413-81232015217.08552016$ Creative Commons (CC BY).

This license lets others distribute, remix, tweak, and build upon your work, even commercially, as long as they credit you for the original creation. This is the most accommodating of licenses offered. Recommended for maximum dissemination and use of licensed materials. 